\title{
EVALUASI PADANG PENGGEMBALAAN ALAMI MARONGGELA DI KABUPATEN NGADA PROVINSI NUSA TENGGARA TIMUR
}

\author{
SIBA, F. G. ${ }^{1)}$, I W. SUARNA ${ }^{2)}$, DAN N. N. SURYANI ${ }^{2)}$ \\ 1) Mahasiswa Program Studi Magister Peternakan Pascasarjana Universitas Udayana \\ 2) Dosen Peternakan Universitas Udayana, Denpasar Bali \\ e-mail: erichgaba2@gmail.com
}

\begin{abstract}
ABSTRAK
Evaluasi terhadap padang penggembalaan alami untuk memperbaiki kualitas hijauan merupakan salah satu strategi penting dalam peningkatan produksi ternak ruminansia. Penelitian ini bertujuan untuk menyediakan database tentang kondisi padang penggembalaan serta pengelolaan padang penggembalaan yang baik di Kabupaten Ngada. Kabupateng Ngada merupakan daerah yang sangat potensial bagi pengembangan ternak sapi karena memiliki padang penggembalaan yang luas. Penelitian dilakukan di padang penggembalaan alami Maronggela Kabupaten Ngada, Provinsi Nusa Tenggara Timur, yang berlangsung selama 2 musim, yaitu pada akhir musim hujan (bulan Maret) dan akhir musim kemarau (bulan Oktober). Peubah yang diamati pada penelitian ini adalah komposisi botani dan kualitas hijauan. Padang penggembalaan alami Maronggela didominasi oleh hijauan jenis Imperata cylindrica dan Themeda aguens, produksi dan kualitas hijauan tertinggi di akhir musim hujan, serta produksi dan kualitas terendah di akhir musim kemarau. Daya tampung padang penggembalaan alami Maronggela dalam satu tahun adalah 1,5 satuan ternak.
\end{abstract}

Kata kunci: database, padang pengembalaan, sapi

\section{EVALUATION OF NATIVE PASTURE IN MARONGGELA, NGADA REGENCY, EAST NUSA TENGGARA PROVINCE}

\begin{abstract}
The evaluation of pasture and rangelands to develope the forage quality is one of important strategy to increase productivity of ruminant. This study aims to provide a database on the condition of pastures and rangelands good management in Ngada. Ngada is an area of high potential for the development of cattle as it has vast pastures. The study was conducted in native pasture Maronggela Ngada, East Nusa Tenggara province, which lasted for two seasons, as of at the end of the rainy season (March) and the end of the dry season (October). The parameters observed in this study are the botanical composition and forage quality. Maronggela natural pasture forage types dominated by Imperata cylindrica and Themeda aguens, the highest forage production and quality at the end of the rainy season, as well as production and quality at the lowest end of the dry season. The capacity of natural pasture Maronggela in one year was 1.5 animal unit.
\end{abstract}

Keywords: database, rangeland, cattle

\section{PENDAHULUAN}

Potensi kekayaan alam yang dimiliki di Indonesia sangatlah berlimpah, salah satunya padang penggembalaan alami. Namun, padang penggembalaan alami di Indonesia sebagian besar tidak diolah dengan baik sehingga kebutuhan konsumsi pakan untuk ternak di Indonesia sangat minim yang menyebabkan rendahnya produksi ternak. Ada beberapa faktor penyebab rendahnya produksi ternak, yaitu: 1) rendahnya kualitas padang penggembalaan alami 2) jumlah ternak yang dipelihara pada padang penggembalaan alami tidak sesuai dengan kapasitas tampung dan 3) keadaan dari tanah di padang penggembalaan.

Kabupaten Ngada tergolong daerah yang beriklim tropis dan terbentang hampir sebagian besar padang rumput yang memiliki luas padang penggembalaan sebesar 17.393 hadengan populasi ternaksapi sebanyak 25.296 ekor (BPS Kabupaten Ngada, 2014). Dinas P3 Ngada (2014) menyatakan bahwa sistem pemeliharaan 
ternak di Kabupaten Ngada dilakukan secara ekstensif berbasis padang penggembalaan yang menyebabkan rendahnya produksi ternak. Dengan demikian, langkah yang dapat ditempuh dalam meningkatkan produksi ternak ruminansia yang dipelihara di Kabupaten Ngada adalah dengan memperbaiki komposisi botanis sehingga kualitas padang penggembalaan alami menjadi meningkat serta pengaturan penggembalaan ternak pada padang penggembalaan alami sesuai dengan kapasitas tampungnya. Upaya untuk memperbaiki komposisi botanis dan peningkatan kapasitas tampung padang penggembalaan alami dapat dilakukan dengan perbaikan komposisi botanis dan kapasitas tampung di lapangan serta penerapan teknologi tepat guna untuk pengolahan hijauan pakan (hay dan silase).

Hijauan pakan alami tidak saja kita temui pada padang penggembalaan alami tetapi juga banyak ditemui pada berbagai kawasan lahan kosong yang memang sengaja atau tidak disengaja memiliki potensi untuk penyediaan hijauan pakan alami. Penelitian yang dilakukan oleh Setiana et al. (2015) mendapatkan bahwa penyediaan hijauan yang dilakukan secara cut and carry di kawasan padat industri Citeureup memiliki potensi yang rendah namun tanaman pakan tersebut sangat adaptif terhadap kondisi lingkungan. Hiajauan pakan local memiliki potensi untuk ditingkatkan kualitasnya, hal tersebut diungkapkan oleh Onesimus (2015) yang menyatakan bahwa dengan pemupukan yang baik akan dapat memperbaiki kualitas hijauan rumput sudan (Sorghum sudanensis) yang merupakan sumber hijauan local potensial di wilayah Papua.

Daya dukung pakan di padang penggembalaan ditentukan oleh jenis tanaman yang dapat tumbuh yang akan berpengaruh terhadap besar kecilnya ketersediaan hijauan yang dapat dikonsumsi ternak. Jenis hijauan yang cocok untuk dibudidayakan pada padang penggembalaan adalah hijauan yang memiliki perakaran yang kuat, tahan pijakan, tahan renggutan, dan tahan terhadap kekeringan. Hasil penelitian padang pengembalaan di NTT menunjukkan bahwa perbandingan antara jenis tumbuhan yang disukai dan kurang disukai ternak adalah masing-masing 77,57 dan 22,43 persen. Produksi bahan hijauan segar berkisar antara 221 sampai $1100 \mathrm{gr} / \mathrm{m}^{2}$ dengan rata-rata $650 \mathrm{gr} /$ $\mathrm{m}^{2}$. Padang savana di NTT memiliki keanekaragaman jenis yang tinggi, produksi bahan segar relatif rendah dan kualitas padang savana rendah. Hal ini terjadi akibat kerusakan padang savana oleh aktivitas manusia yang meliputi pemanfaatan yang tidak terencana dan pembakaran padang penggembalaan pada musim kering (Robinson, 1995).

Sampai saat ini evaluasi mengenai padang penggembalaan sudah dilakukan di beberapa Kabupaten di Nusa Tengaara Timur. Sedangkan studi yang sama di Kabu- paten Ngada belum pernah dilakukan. Oleh karenanya, dalam upaya melengkapi informasi mengenai evaluasi padang penggembalaan perlu dilakukan studi "evaluasi padang penggembalaan alami Maronggela di Kabupaten Ngada, Provinsi Nusa Tenggara Timur.

\section{MATERI DAN METODE}

Penelitian dilakukan di padang penggembalaan alami Maronggela Kabupaten Ngada, Provinsi Nusa Tenggara Timur. Penelitian berlangsung selama 2 musim, yaitu pada akhir musim hujan (bulan Maret) dan akhir musim kemarau (bulan Oktober) 2015.

Jumlah sampel yang diambil yaitu sebanyak 100 cuplikan, dimana 50 cuplikan diambil di lokasi lereng, 35 cuplikan di lokasi datar dan 15 sampel di lokasi dekat kali. Jumlah pengambilan cuplikan di tiga lokasi (lereng, datar dan dekat kali) didasari oleh topografi padang penggembalaan alami Maronggela yang berbukit-bukit dimana hampir sebagian besar padang penggembalaan merupakan lereng bukit, daerah datar terdapat pada puncak bukit dan daerah kali terletak antara bukitbukit.

Komposisi botani dihitung untuk mengetahui komposisi atau susunan spesies hijauan. Pada penelitian ini komposisi botani dihitung berdasarkan frekuensi (keseringan), sedangkan kualitas hijauan ditentukan dengan analisis nilai nutrien, meliputi bahan kering (BK), bahan organik (BO), protein kasar (CP), energi (E), serat kasar (SK), kalsium (Ca), fosfor (P). Penelitian yang dilakukan oleh Onesimus et al. (2015) menunjukkan bahwa spesies hijauan yang mendominasi padang penggembalaan alam Kebar adalah jenis rumput yaitu Imperata cylindrica, Paspalum conjugatum, dan Ischaemum rugosum, dan Kyllinga brevifolia. Komposisi botani padang penggembalaan alam lokasi Inam adalah $87,58 \%$ rumput, 0,52\% legum, dan $11,90 \%$ hijauan non pakan, sedangkan lokasi Jandurau berturut-turut $81,88 \%$ rumput, $0,75 \%$ hijauan dapat dikonsumsi, dan $17,39 \%$ hijauan non pakan. Produktivitas padang penggembalaan alam dataran 65 Kebar dapat ditingkatkan dengan introduksi spesies yang cocok dan potensi produksi tinggi dan/atau perlu dilakukan program pemberian pakan tambahan (dasar hijauan pakan).

\section{HASIL DAN PEMBAHASAN}

Berdasarkan hasil pengamatan pada musim kemarau dan musim hujan pada tiga lokasi (datar, lereng, dekat kali) padang penggembalaan alami Maronggela, hampir semuanya didominasi oleh Imperata cylindrica, hal ini dikarenakan tanaman ini sangat mudah beradaptasi baik pada musim hujan maupun pada musim kemarau, juga pada lokasi datar, lereng dan dekat kali. Selain 
itu Imperata cylindrica merupakan tanaman yang berkembang biak dengan biji atau rhizom (akar rimpang), sehingga dapat berkembangbiak dengan cepat.

Tabel 1. Komposisi botani berdasarkan frekuensi (keseringan)

\begin{tabular}{llcccc}
\hline \multirow{2}{*}{ Lokasi } & \multirow{2}{*}{ Spesies Tanaman } & \multicolumn{2}{c}{ Musim Hujan } & \multicolumn{2}{c}{ Musim Kemarau } \\
\cline { 3 - 6 } & & Frekuensi & $\%$ & Frekuensi & $\%$ \\
\hline Datar & Themeda gigantea & 18 & 51,43 & - & - \\
& Imperata cylindrica & 31 & 88,57 & 25 & 71,43 \\
& Mimosa pudica & 14 & 40,00 & - & - \\
& Leptochloa chinesis & 6 & 17,14 & - & - \\
& Cyperus rotundus & 12 & 34,29 & - & - \\
& Themeda arguens & 17 & 48,57 & 16 & 45,71 \\
& Gulma & 33 & 94,29 & 22 & 62,86 \\
Lereng & Themeda Gigantea & 50 & 100 & - & - \\
& Imperata Cylindrica & 50 & 100 & 32 & 64 \\
& Themeda Arquens & 35 & 70 & 16 & 32 \\
& Mimosa Pudica & 20 & 40 & - & - \\
Dekat Kali & Themeda Gigantea & 11 & 73,33 & - & - \\
& Imperata Cylindrica & 13 & 86,67 & - & - \\
& Mimosa Pudica & 8 & 53,33 & - & - \\
Themeda arguens & - & - & 11 & 73,33 \\
Gulma & 11 & 73,33 & 11 & 73,33 \\
\hline
\end{tabular}

Themeda arguens merupakan jenis hijauan yang populasinya cukup dominan setelah Imperata cylindrica. Hijauan ini sering tumbuh bersama Imperata cylindrica dan merupakan tumbuhan tahunan, yang membentuk padang sabana. Selain hijauan, dalam padang penggembalaan alami Maronggela juga terdapat gulma yang populasinya cukup tinggi. Jenis gulma yang terdapat dalam padang penggembalaan ini adalah Chromolaena odorata. Gulma jenis ini memliki kemampuan mendominasi area dengan sangat cepat, hal ini didukung karena jumlah biji yang dihasilkan sangat melimpah. Setiap tumbuhan dewasa mampu memproduksi sekitar 80 ribu biji setiap musim. Kepadatan tumbuhan bias mencapai 36 batang tiap $\mathrm{m}^{2}$ yang berpotensi menghasilkan kecambah, tunas dan tumbuhan dewasa berikutnya (Yadav dan Tripathi 1981).

Berdasarkan produksi hijauan diperoleh bahwa Daya tampung padang penggembalaan alami Maronggela dalam satu tahun adalah 1,5 satuan ternak. Hasil tersebut lebih rendah daripada daya tampung hijauan yang diperoleh Onesimus et al. (2014) yakni sebesar 2 unit ternak per ha padang penggembalaan alami di Papua Barat.

Berdasarkan hasil analisis proksimat yang dilakukan di Laboratorium Balai Penelitian Ternak CiawiBogor, diperoleh rata-rata jumlah kandungan protein hijauan pada musim hujan yaitu 4,16\% dan rata-rata kandungan protein hijauan pada musim kemarau yaitu
2,78\%. Hal ini menggambarkan rendahnya kualitas hijauan pakan pada padang penggembalaan alami Maronggela. Menurut Siregar (1994), bahwa hijauan dikategorikan pada kualitas rendah bila kandungan protein kasarnya kurang dari 5\%, dikatakan sedang bila kandungan protein kasarnya 5-10\% dan tinggi bila protein hijauannya lebih besar dari 10\%.

Tabel 2. Hasil analisis hijauan padang penggembalaan alami Maronggela

\begin{tabular}{|c|c|c|c|c|c|c|c|c|}
\hline \multirow{2}{*}{$\begin{array}{c}\text { Komposisi Kimia } \\
\text { Hijauan }\end{array}$} & \multicolumn{3}{|c|}{ Musim Hujan } & \multirow{2}{*}{-rata-rata } & \multicolumn{3}{|c|}{ Musim Kemarau } & \multirow{2}{*}{$\begin{array}{c}\text { Rata- } \\
\text { rata }\end{array}$} \\
\hline & D & $\mathrm{L}$ & DK & & D & $\mathrm{L}$ & DK & \\
\hline tein (g / $100 \mathrm{~g}$ ) & 4,26 & 4,09 & 4,14 & 4,16 & 2,46 & 2,75 & 3,13 & 2,78 \\
\hline hergi (Kcal / kg) & 3724 & 3691 & 3702 & 3705,67 & 3559 & 3683 & 3545 & 3595,67 \\
\hline $\mathrm{K}$ (g / $100 \mathrm{~g})$ & 39,60 & 42,7 & 40,96 & 41,09 & 35,93 & 35,54 & 39,28 & 36,92 \\
\hline Abu (g / $100 \mathrm{~g}$ ) & 10,43 & 10,1 & 9,85 & 10,11 & 11,9 & 11,19 & 9,23 & 10,77 \\
\hline $\mathrm{Ca}(\mathrm{g} / 100 \mathrm{~g})$ & 0,31 & 0,26 & 0,28 & 0,28 & 0,34 & 0,43 & 0,36 & 0,38 \\
\hline (g / $100 \mathrm{~g})$ & 0,08 & 0,08 & 0,08 & 0,08 & 0,03 & 0,04 & 0,05 & 0,04 \\
\hline
\end{tabular}

Kualitas hijauan pakan tergolong rendah disebabkan karena komposisi botani hijauan sebagian besar adalah jenis rumput alami dan tanpa leguminosa. Kondisi padang penggembalaan ini akan berdampak pada rendahnya produktivitas ternak karena kebutuhan minimal PK bagi ternak ruminansia sebesar $8 \%$ tidak terpenuhi. Rumput alam tidak mampu memenuhi kebutuhan nutrien ternak, dan ternak yang sedang dalam periode pertumbuhan akan memperlihatkan tingkat pertambahan bobot badan yang rendah. Ketersediaan dan kualitas nutrien rumput alam juga akan makin menurun saat musim kering dan hal ini akan berpengaruh terhadap produktivitas ternak.

\section{SIMPULAN}

Komposisi botani padang penggembalaan alami Maronggela didominasi oleh hijauan jenis Imperata cylindrica dan Themeda aguens, produksi dan kualitas hijauan, serta daya tampung padang penggembalaan alami Maronggela mengalami fluktuasi sesuai musim, produksi tertinggi di akhir musim hujan, kualitas terbaik di musim hujan serta produksi dan kualitas terendah di akhir musim kemarau. Daya tampung padang penggembalaan alami Maronggela dalam satu tahun adalah 1,5 satuan ternak.

\section{DAFTAR PUSTAKA}

Arismunandar. 1983. Mendayagunakan Tanaman Rumput. Sinar Baru: Bandung

BPS Kabupaten Ngada, 2014. Kabupaten Ngada Dalam Angka 2014. BPS Kabupaten Ngada. 
Dinas P3 (Pertanian, Perkebunan dan Peternakan) Kabupaten Ngada, 2014. Rencana Strategis (Renstra) Dinas Peternakan Kabupaten Ngada 2010-2015. Dinas Peternakan Kabupaten Ngada.

Onesimus Yoku, A.Supriyantono, T. Widayati dan I. Sumpe. 2014. Produksi padang penggembalaan alam dan potensi pengembangan sapi bali dalam mendukung program kecukupan daging di Papua Barat. J. Pastura, 3 (2): $102-105$.

Onesimus Y. 2015. Potensi Produksi Hijauan dan Komposisi Kimia Rumput Sudan (Sorghum sudanense) Sebagai Sumber Hijauan Pakan Lokal Di Wilayah Papua. Prosiding Semnas IV HITPI. Purwokerto.

Onesimus Y. A. Supriyantono, T. Widayati dan I. Sumpe. 2015. Komposisi botani dan persebaran jenis-jenis hijauan lokal padang pengembalaan alam di Papua Barat. J. Pastura, 4 (2): 62 -65.

Reksohadiprojo, S. 1994. Produksi Tanaman Hijauan Makanan Ternak Tropik. BFFE, Yogyakarta.
Robinson. H. 1995. Komposisi Janis Hijauan pada Padang Savana Penggembalaan diDesa Oemasi, Timor, NTT. Prosiding Seminar Nasional Peternakan dan Veteriner(Cisarua Bogor, 7-8 Nopember 1995). Bogor; Puslit Peternakan. Bogor. hlm. 545 -552.

Setiana MA, Ikmahwati S, Yakin A, dan Prihantoro I. 2015. Pola Penyediaan dan Potensi Hijauan Di Kawasan Industri Kecamatan Citeureup Kabupaten Bogor. Prosiding Semnas IV HITPI. Purwokerto.

Subagyo I. dan Kusmartono. 1988. Ilmu Kultur Padangan. Malang: Nuffic, Fakultas Peternakan Universitas Brawijaya.

Susetyo, I. Kismono dan B. Suwardi. 1981. Hijauan Makanan Ternak. Direktorat Jendral Peternakan Departemen Pertanian, Jakarta.

Yadav, A.S. and R.S. Tripathi. 1981 Population dynamics of the rudern weed Eupatarium odoratum and it's natural regulation. Oikes. 36 (3): 355 -361. 